\title{
The Constitutional Case LaW of Japan, 1970 THROUGH 1990
}

\author{
Lawrence N Beer and Hiroshi Itoh, University of Washington Press, Seattle, \\ 1996. Pages $i-x i v, 1-688$ including appendices and index \\ Reviewed by AH Angelo*
}

Professors Beer and Itoh are to be congratulated on what they describe as their "modest mitigation"1 of the problems associated with access to Japanese law for non-Japanese readers.

This book contains 47 judgments of Japanese courts on constitutional matters delivered in the period 1970-1990. This book continues the tradition of English language access to Japanese constitutional law decisions begun in 1964 with the publication by John Maki of Court and Constitution of Japan: Selected Supreme Court Decisions, 1948-1960 (University of Washington Press), and continued with the 1978 volume (published by Itoh and Beer in the Asian Law Series to which the present book belongs) entitled The Constitutional Case Law of Japan: Selected Supreme Court Decisions, 1961-70 (University of Washington Press). Appendix 4 of this volume brings together in an accessible form a list of all the translations of Japanese constitutional decisions published in those three volumes. The total is 107 reports. The work of these authors, editors and translators over a number of years is an impressive one. The task of translation alone is formidable, requiring as it does both bilingualism and bi-juralism. For the present volume a team of 27 eminent scholars participated in the translation work and the production of a volume in which the material is both accessible and comprehensible.

In the book under review, most of the cases are decisions of the Supreme Court of Japan. This court has dealt with a very large number of cases over the years, and the table on page 66 indicates the volume of litigation currently handled by it and other courts in the Japanese legal system. An indicative figure is that of 1990 in which the Supreme Court dealt with 1,971 criminal cases and 2,224 non-criminal cases, with approximately 2,000 cases pending.

* Professor of Law, Victoria University of Wellington.

1 Page $x$. 
Some $80 \%$ of the cases filed with the Supreme Court are (page 20) eliminated by research judges who assist the Supreme Court Justices.

The editors, in the Introduction, provide a overview of Japan's constitutional law since 1945 and set the judicial developments in the general context of the Constitution of Japan, in its political setting and, more generally, in an international frame. The Introduction provides a very positive view of world constitutional developments generally, and of the role of the two main Western legal traditions. This positive view of universal developments is salutary, accepting that the developments are as assessed in the Introduction. It is also relevant to consider whether the developments are being driven by idealism or more simply by the economic constraints and encouragements provided by the states of Western Europe, Japan and North America. As is stated on page 6 "a country's capacity to participate in this world legal dialogue depends on its degree of legal development". The Japanese example of the 19th century shows that legal development may not flow from any necessary predilection but rather from political necessity or pragmatism. The pressure of the international economy and its impact in the developing countries of the world is very great.

Contemporary political events show that there is perhaps more need for optimism than cause for optimism in international constitutional developments. Both Japan and New Zealand have been fortunate in that neither has been a state at war since 1945, though both have had incidents of internal unrest - which have often surprised national and outside observers by how readily violence is resorted to in defence of a cause. For Japan, perhaps even more than New Zealand, peacefulness has since 1945 replaced militarism (page 3). As a result of article 9 of its Constitution, Japan has renounced war and rigorously kept apart from international military activities. On the other hand, in $1945 \mathrm{New}$ Zealand was involved militarily abroad and has since then had a regular presence in areas of war and civil strife around the world. Sometimes this has been on the side of a belligerent, but more typically as part of an international military or civilian contingent (Cyprus, Iraq, Yugoslavia, Cambodia).

New Zealand came of age with the conflagration of 1939 and acceded to constitutional independence in 1947. In that sense, the constitutional history of New Zealand and Japan had a common way point. Japan, in 1946, established (or continued, depending on ones view of history) its Upper House; in 1951 New Zealand abolished its Upper House. Now with the major reconfiguration of world political and trading patterns, Japan and New Zealand are major trading partners. Both have seen great changes in human rights matters over the last 50 years - Japan in respect of nationality matters and accession to international human rights conventions for instance, and New Zealand in respect of international human rights conventions and indigenous peoples issues. Both have in the last few years made substantial changes to their electoral laws. In New Zealand, this was arguably a major constitutional change going to the heart of the operation of its 
constitution. In the case of Japan, it was technically a matter outside of the Constitution and therefore conceivably a matter of lesser legal significance. ${ }^{2}$ Another feature shared by the two states has been the increasing role of the judiciary in constitutional matters. In the case of Japan it has been the job of the judiciary and particularly of the Supreme Court of Japan to give meaning to the Constitution of 1946. That judicial activity has given real substance and a Japanese quality to the words, many of which were translated from English to Japanese in the context of the activities of SCAP in $1946 .{ }^{3}$ In New Zealand the task of the courts has been the creating of New Zealand constitutional norms. This has happened in the context of general cases such as Fitzgerald $v$ Muldoon ${ }^{4}$ but more particularly and significantly in the development of the law under the New Zealand Bill of Rights Act $1990^{5}$ and in relation to the Treaty of Waitangi. ${ }^{6}$

The Japanese constitutional law is significant not only as that of a major world power, but also as a body of law that has been consistently and coherently developed by an eminent body of judges in the context of a constitution which is now one of only about 20 which have remained unchanged in the period since 1950.

This book is not a textbook on Japanese constitutional law. As is indicated at page 54, much constitutional law lies outside the realm of judicial review. The reader and researcher therefore needs to go beyond the seminal cases to get a full view of constitutional activity in Japan. A New Zealand reader with an interest in indigenous peoples law and minority rights, may be interested for instance in the Japanese legal developments in respect of minorities such as the Ainu, the Korean community and the Burakumin. ${ }^{7}$ There is no consideration in this text of the extensive legal and political development in Japan on these issues. Instead, the book is a record of 47 seminal judgments. The editors conclude that the judgments show that the Supreme Court has been both restrained and conservative (page 54) and that it has not been a catalyst for social change. It has in general not been subservient to other sectors of the Japanese constitution, but "judicial restraint and conservatism are rooted deeply in the nature of post-1945 politics" (page 54). The court has "avoided a confrontation with the political branches". Even in respect of the currently significant issue under article 25 of the Constitution and electoral malapportionment in Japan of 5.26:1 (page 51) the court has been cautious in its approach, and the Diet in its turn has in general been

2 See Asaka, in this volume.

3 See Tsutsui, in this volume.

4 [1976] 2 NZLR 615.

5 Simpson v Attorney-General (Baigent's case) [1994] 3 NZLR 667.

6 New Zealand Maori Council v Attorney-General [1989] 2 NZLR 142.

7 Hereditary outcasts. 
respectful of and responsive to the views of the Supreme Court. By way of comparison, the judicial approach to the facts in the New Zealand cases of Simpson $v$ Attorney-General, ${ }^{8}$ and Fitzgerald $v$ Muldoon ${ }^{9}$ may be noted.

The Introduction with 54 pages with 10 pages of notes, is excellent. It is supported (on page 66) with a chart indicating the case load of Japan's judiciary. ${ }^{10}$ Appendix 1 lists the Supreme Court Justices of Japan 1971-1990, Appendix 2 maps the court jurisdictions in Japan, Appendix 3 sets out an English translation of the Japanese Constitution, Appendix 4 is a list of constitutional law cases in English, ${ }^{11}$ and Appendix 5 contains notes on the translators involved in producing this text.

Inevitably, perhaps, having been presented with an excellent text, there is a desire for something more. In this case it would have been helpful, since the book was published in 1996 and since Appendix 1 does refer to dates post-1990, to have had the list brought up to a more recent date. Equally it would have been interesting (and helpful for an understanding of Japanese constitutional process) to have had a list of the Chief Justices for the period, and even a statement of the composition of the Supreme Court at publication date, so that a clearer picture of the Supreme Court may be obtained. At page 25 comment is made about the changing Cabinet in Japan - what is the rate of turnover in the Supreme Court? None of these points however serve to detract from what is an excellent volume, a book essential for inclusion on the reference shelves of all interested in legal and political developments in Japan.

8 [1955] NZLR 271.

9 See above $\mathrm{n} 4$.

10 This chart is not listed in the contents list or in the index.

11 As is mentioned in the Preface, the General Secretariat of the Supreme Court of Japan has published a Series of Prominent Judgments of the Supreme Court upon Questions of Constitutionality. It would also have been helpful for the use of the book as a reference text to have had listed in Appendix 4 those judgments that appear in English translation in the Supreme Court series. 